Mansur : Model Pemanfaatan Hasil Hutan Bukan Kayu (HHBK) Bagi Masyarakat di Zona Tradisional Taman Nasional Bantimurung Bulusaraung

\title{
MODEL PEMANFAATAN HASIL HUTAN BUKAN KAYU (HHBK) BAGI MASYARAKAT DI ZONA TRADISIONAL TAMAN NASIONAL BANTIMURUNG BULUSARAUNG
}

\author{
(The Utilization Models of Non Timber Forest Production (Hhbk) for the Local \\ People in the Traditional Zone of Bantimurung Bulusaraung National Park)
}

\author{
Mansur $^{1}$, Amir Tjoneng ${ }^{2}$ dan Saida ${ }^{2}$ \\ ${ }^{1}$ Pascasarjana Universitas Muslim Indonesia \\ E-mail : syu_rah77@yahoo.co.id \\ ${ }^{2}$ Fakultas Pertanian Universitas Muslim Indonesia Makassar
}

\begin{abstract}
The community's need for land is very basic and continues to increase. With the expanding population and socio-economic activity, the uses of land is not only for a place to live, but rather to strive in order to survive, especially for rural communities. The National Park is an area that has specific characteristics, that have been defined for the function as a buffer system to protection of life by maintaining the existence of the original ecosystem in the expanse ecoregions. Bantimurung Bulusaraung National Park (TNBabul) with all the potentials and characteristics running these function by fixed pay attention and accommodate the needs of the local community especially in terms of land use and utilization. The various conflicts that occur as a result of government policies on land today need to be taken seriously by all parties. To carry out the management and land use with the protection functions, required comprehensive management regulatory mechanism involving all stakeholders. This study aims to identify, analyze and formulate a pattern management and land use on the TNBabul ecosystem sustainability and community survival. Land utilization and management by the community at TNBabul is done adaptively, one of them is non-timber forest products (HHBK) harvesting as an socio-economic effort in order to survive.
\end{abstract}

Keywords: National park, Land use and utilization, Stakeholder, Adaptively.

\section{PENDAHULUAN}

Zonasi Taman Nasional

Bantimurung Bulusaraung ditetapkan

berdasarkan Keputusan Direktur Jenderal

Perlindungan Hutan dan Konservasi Alam

Nomor: SK.58/IV-SET/2012 tanggal 4

April 2012 mengaju Peraturan Menteri

Kehutanan Nomor: P.56/Menhut-II/2006

tentang Pedoman Zonasi Taman Nasional,

yang telah direvisi menjadi Peraturan

Menteri Lingkungan Hidup dan
Kehutanan Nomor: P.76/Menlhk-

Setjen/2015. Zonasi TN Bantimurung Bulusaraung tersebut dirancang dengan mengkompilasikan seluruh data dan informasi terkait potensi sumberdaya alam hayati dan ekosistemnya, permasalahan dan potensi konflik di dalam dan sekitar kawasan, serta memperhatikan hak-hak masyarakat setempat yang lahir karena kesejarahan dan kondisi aktualnya sebagai 
Mansur : Model Pemanfaatan Hasil Hutan Bukan Kayu (HHBK) Bagi Masyarakat di Zona Tradisional Taman Nasional Bantimurung Bulusaraung

akibat penunjukan kawasan TN sebagian kecil lainnya merupakan tegakan

Bantimurung Bulusaraung.

Zona Tradisional TN Bantimurung

Bulusaraung meliputi kawasan seluas

4.374,05 ha atau sebesar $10,00 \%$ dari total luas taman nasional. Zona Tradisional TN

Bantimurung Bulusaraung meliputi ketiga tipe ekosistem yang ada di dalam kawasan. Tipe ekosistem terluas yang terwakili di dalam zona tradisional adalah ekosistem Hutan Hujan Non Dipterocarpaceae Pamah seluas 3.860,21 ha atau sebesar $8,82 \%$ dari total luas kawasan taman nasional. 469,79 ha atau sebesar $1,07 \%$ dari total luas kawasan taman nasional merupakan tipe ekosistem Karst yang terwakili di dalam Zona Tradisional. Adapun tipe ekosistem Hutan Pegunungan Bawah terwakili di dalam Zona Tradisional seluas 44,05 ha atau sebesar $0,10 \%$ dari total luas kawasan taman nasional.

Sebagian besar area Zona Tradisional pada kawasan TN Bantimurung Bulusaraung terletak di wilayah administratif kabupaten Maros dan hanya sebagian kecil yang berada di wilayah administratif kabupaten Pangkep. Zona Tradisional ini pada umumnya merupakan areal yang ditumbuhi oleh tegakan Kemiri (Aleurites moluccana) dan
Pinus (Pinus merkusii) yang homogen.

Kemiri tersebut telah dibudidayakan oleh masyarakat setempat sejak beberapa generasi sebelumnya. Sebagian besar Zona Tradisional TN Bantimurung Bulusaraung berada di ekosistem Hutan Hujan Non Dipterocarpaceae Pamah karena kesesuaian kondisi lingkungan biofisiknya dengan persyaratan tumbuh jenis Kemiri.

Masyarakat masih sangat bergantung dari hasil hutan, dalam hal ini Hasil Hutan Bukan Kayu (HHBK) yakni madu hutan, gula aren, bambu, porang/tire. Selain itu masyarakat Desa Labuaja memiliki permasalahan secara teknis dalam hal pengelolaan ternak berupa sapi. Kolaborasi dalam pengelolaan pakan ternak dan pemanfaatan HHBK sangat diperlukan guna mendukung peningkatan kesejahteraan masyarakat tanpa mengurangi fungsi ekologi hutan, terutama untuk menjawab tantangan global dalam hal kebutuhan masyarakat.

Kawasan TN Bantimurung Bulusaraung dengan segala potensi dan keunikannya perlu dikelola dengan baik sesuai kaidah-kaidah pengelolaan hutan yang berlaku, pengelolaan dapat 
Mansur : Model Pemanfaatan Hasil Hutan Bukan Kayu (HHBK) Bagi Masyarakat di Zona Tradisional Taman Nasional Bantimurung Bulusaraung

dilaksanakan secara efektif dan terstruktur maka arahan pengelolaan, serta tujuan dan sasaran pengelolaan harus jelas. Pengelolaan kawasan TN Bantimurung Bulusaraung sedapat mungkin mampu mengakomodir berbagai kepentingan berdasarkan fungsi pokoknya secara lestari, seimbang dan berkesinambungan. Pengelolaan kawasan TN Bantimurung Bulusaraung diarahkan pada pencapaian multi manfaat kawasan dengan tetap mengacu pada prinsip-prinsip kelestarian.

Berdasarakan uraian tersebut, maka perlu dilakukan penelitian untuk mengkaji Model Pemanfaatan Hasil Hutan Bukan Kayu Bagi Masyarakat di Zona Tradisional Taman Nasional Bantimurung Bulusaraung.

\section{METODE PENELITIAN}

Penelitan ini dilaksanakan dari bulan April 2017 sampai dengan bulan Juli 2017. Lokasi penelitian yaitu di Dusun Pattiro Desa Labuaja Kecamatan Cenrana Kabupaten Maros. Pemilihan lokasi tersebut dengan pertimbangan bahwa di lokasi ini merupakan areal yang sebelumnya terdapat kegiatan Eks-HKm, dimana masyarakat sudah banyak melakukan pemanfaatan lahan pada areal tersebut dan sebagian besar masuk ke dalam areal kawasan Taman Nasional Bantimurung Bulusaraung.

\section{Teknik Pengumpulan Data}

Teknik pengumpulan data yang digunakan adalah:

a. Wawancara berstruktur dengan menggunakan daftar kuisioner.

b. Observasi, yaitu pengumpulan data primer yang dilakukan dengan cara mengadakan pengamatan langsung terhadap fenomena-fenomena yang tampak pada objek penelitian di lapangan.

c. Dokumentasi, yaitu dengan melakukan pencatatan dan pengambilan gambar di lapangan melalui pemotretan dan fotocopy data sekunder dari instansi terkait.

d. Selain itu, juga dipergunakan tehnik Focus Group Discussion (FGD) dengan melibatkan beberapa tokoh masyarakat. Untuk mencari hal-hal yang berkaitan dengan kegiatan di areal kawasan Taman Nasional Bantimurung Bulusaraung.

\section{Metode Analisis}

Metode analisis data secara statistik deskriptif dan Analisis Rasio

- Analisis Rasio

Analisis ini digunakan untuk mengetahui sejauh mana tingkat 
pendapatan masyarakat dan kelompok tani hutan dalam menggunakan tipe pemanfaatan yang dilakukan di Zona Tradisional TN Bantimurung Bulusaraung dgn penggunaan Analisis Ratio (Revenue Cost Ratio) merupakan efisiensi usaha, yakni ukuran perbandingan antara Penerimaan Usaha (Revenue $=R$ ) dengan Total Biaya $($ Cost $=T C)$.

Rumus R-e Rasio

Ratio $=$ Total Penerimaan $(T R)-$ Total Biaya Produksi (TC)

$$
\mathrm{Y}=\mathrm{TR}-\mathrm{TC}
$$

\section{HASIL DAN PEMBAHASAN}

\section{Pemanfaatan Lahan di Zona Tradisional}

Pola penggunaan lahan oleh masyarakat dalam kawasan Taman Nasional Bantimurung Bulusaraung masih bersifat tradisional dan sederhana, hal ini merupakan kebiasaan turun-temurun bagi masyarakat yang ada. Pola-pola pemanfaatan lahan yang terdapat di dalam areal Taman Nasional Bantimurung Bulusaraung adalah hutan alam, hutan tanaman jati, sawah, perkebunan (kebun campuran, kebun tanaman semusim, ladang), semak belukar, dan pemukiman. Masyarakat yang terdapat di Zona
Tradisional memiliki lahan yang mereka manfaatkan untuk kegiatan kehutanan, pertanian dan perkebunan. Untuk kegiatan pertanian terdapat sawah tadah hujan dengan panen sekali dalam setahun. Diantara potensi pertanian dan jenis tanaman yang diusahakan masyarakat Desa Labuaja adalah porang dan rumput gajah, selain tanaman pertanian masyarakat juga mengusahakan Hasil Hutan Bukan Kayu (HHBK) seperti madu hutan, nira aren dan bambu.

\section{Pendapatan Masyarakat Di Zona Tradisional Taman Nasional Bantimurung Bulusaraung}

Analisis pendapatan dilakukan untuk mengetahui faktor-faktor hasil investasi dan biaya investasi yang telah dibangun oleh masyarakat dalam pemanfaatan lahan dan pemungutan Hasil Hutan Bukan Kayu (HHBK) di zona tradisional Taman Nasional Bantimurung Bulusaraung. Adapun beberapa pemanfaatan lahan dan pemungutan Hasil Hutan Bukan Kayu (HHBK) yang diusahakan masyarakat dalam kelompok tani hutan Bukit Harapan, Bulu Tanete, Tunas Muda dan Pattiro Bulu adalah Madu hutan, nira aren, bambu, rumput gajah dan porang. 
Mansur : Model Pemanfaatan Hasil Hutan Bukan Kayu (HHBK) Bagi Masyarakat di Zona Tradisional Taman Nasional Bantimurung Bulusaraung

\begin{tabular}{lccccc}
\hline \multicolumn{1}{c}{ Kelompok Tani } & MADU & $\begin{array}{c}\text { NIRA } \\
\text { AREN }\end{array}$ & PORANG & BAMBU & $\begin{array}{c}\text { RUMPUT } \\
\text { GAJAH }\end{array}$ \\
\hline Bukit Harapan & $4,300,000$ & $12,552,000$ & $2,600,000$ & $6,420,000$ & $4,935,000$ \\
Bulu Tanete & $5,840,000$ & $25,272,000$ & 520,000 & $9,630,000$ & $7,393,750$ \\
Tunas Muda & $10,960,000$ & $14,784,000$ & $2,600,000$ & - & $5,573,750$ \\
Pattiro Bulu & $6,660,000$ & $11,820,000$ & $1,560,000$ & - & $5,643,750$ \\
\hline \multicolumn{1}{c}{ JUMLAH } & $\mathbf{2 7 , 7 6 0 , 0 0 0}$ & $\mathbf{6 4 , 4 2 8 , 0 0 0}$ & $\mathbf{7 , 2 8 0 , 0 0 0}$ & $\mathbf{1 6 , 0 5 0 , 0 0 0}$ & $\mathbf{2 3 , 5 4 6 , 2 5 0}$ \\
\hline
\end{tabular}

\section{KESIMPULAN}

1. Bentuk pemanfaatan lahan dan Hasil Hutan Bukan Kayu masyarakat pada areal Taman Nasional Bantimurung Bulusaraung meliputi pemanfaatan lebah madu, nira aren, bambu, rumput gajah (pakan ternak), dan porang.

2. Masyarakat Dusun Pattiro, Desa Labuaja memiliki ketergantungan yang tinggi terhadap areal Taman Nasional Bantimurung Bulusaraung dalam memenuhi kebutuhan sehariharinya. Analisis pendapatan kelompok tani menunjukkan nilai ekonomi pada pemanfaatan lebah madu sebesar Rp. 27,760,000, nira aren sebesar Rp. 64,428,000, rumput gajah sebesar Rp. 23,546,250, bambu sebesar Rp. 16,050,000, dan porang sebesar Rp. 7,280,000

3. Model pemanfaatan Hasil Hutan Bukan Kayu (HHBK) yang paling bagus untuk diusahakan oleh masyarakat adalah Nira Aren nilai potensi yang lebih besar dibanding dengan potensi yang lain.

\section{DAFTAR PUSTAKA}

Arief, A. 2001. Hutan dan Perhutanan. Kanisius, Yogyakarta.

Arsyad, S. 2010. Konservasi Tanah dan Air. Institut Pertanian Bogor, Bogor.

Balai Taman Nasional Bantimurung Bulusaraung, 2012. Profil daerah penyanga taman nasional bantimurung bulusaraung.

Balai Taman Nasional Bantimurung Bulusaraung, 2015. Revisi zonasi taman nasional bantimurung bulusaraung.

Balai Taman Nasional Bantimurung Bulusaraung, 2016. Laporan evaluasi kinerja pengelolaan taman nasional (tn) bantimurung bulusaraung.

Balai Taman Nasional Bantimurung Bulusaraung, 2016. Rencana pengelolaan jangka panjang taman nasional bantimurung bulusaraung provinsi sulawesi selatan periode tahun 2016 - 2025. 
Benyamin Dendang, IPB Bogor, 2013. Potensi trichoderma spp. Sebagai agens hayati dalam pengendalian ganoderma sp. yang menyerang tanaman sengon.

Departemen Kehutanan dan Perkebunan. 2000. Rencana Strategik Penyuluhan Kehutanan dan Perkebunan, Pusat Bina Penyuluhan Kehutanan dan Perkebunan, Jakarta.

Hasanuddin, 2006. Studi Potensi Konflik Penggunaan Lahan oleh Masyarakat di Dalam dan Sekitar Taman Nasional Bantimurung Bulusraung, Skripsi program Studi Manajemen Hutan, Fakultas Pertanian dan Kehutanan Unhas-Makassar.

Iskandar, J., 1992. Ekologi Perdagangan di Indonesia, Studi Kasus dari daerah Badui Selatan, Jawa Barat, Pernit Jambatan, Jakarta.

IUCN. 1994. Guidelines for Protected Area Management Categories. CNPPA wiyh the assistance of WCMC. UK : IUCN, Gland, Switzerland and Cambridge.

Jaica, 2009. The Field Review Report in Sulawesi Selatan Province, Ministry Of Foretry, Jakarta.

Kadir, Ichwan M, 2012. Analisis Kompensasi Tanaman Masyarakat Didalam Kawasan Taman Nasional Bantimurung Bulusaraung Desa Labuaja Kecamatan Cenrana Kabupaten Maros Sulawesi Selatan (Studi Kasus Pak Patu), Fakultas Kehutanan Unhas-Makassar.

Kartodiharjo, H. 1998. Analisis Kebijakan Pengelolaan Hutan Alam Produksi Di
Indonesia. Fakultas Kehutanan IPB. Bogor.

Keputusan Menteri Kehutanan Nomor 31 Tahun 2001. Tentang Penyelenggaraan Hutan Kemasyarakatan.

Mubyarto, 1992. Desa dan Perhutanan Sosial, Kajian Sosial Antropologis di Provinsi Jambi.

Muh. Sabir, 2014. Faktor-faktor yang Mempengaruhi Perilaku Petani dalam Melakukan Konservasi Tanah dan Air secara Berkelanjutan di Daerah Penyangga Kawasan Taman Nasional Bantimurung Bulusaraung.

Nasution M. 1999. Untuk Mewujudkan Pembangunan Kehutanan dan Perkebunan yang Berkeadilan dan Berkelanjutan. Kumpulan Orasi dan Pidato. DepartemenKehutanan dan Perkebunan. Edisi ke-2. Jakarta.

Peraturan Menteri Kehutanan Nomor: P.56/Menhut-II/2006 Tentang Pedoman Zonasi Taman Nasional. Jakarta: Direktorat Jenderal Perlindungan Hutan dan Konservasi Alam.

Soemarwoto, dkk. 1992. Melestarikan Hutan Tropiks, Permasalahan, Manfaat dan kebijaksanaanya, Penyunting Mochtar Lubis. Yayasan Obor Indonesia, Jakarta.

Supratman, 2011. Manajemen Hutan Berbasis Desa : Interaksi antara Sistem Pengelolaan Hutan Lestari dengan Sistem Kelembagaan Lokal. Hasanuddin University Press. Makassar. 
Mansur : Model Pemanfaatan Hasil Hutan Bukan Kayu (HHBK) Bagi Masyarakat di Zona Tradisional Taman Nasional Bantimurung Bulusaraung

Undang-Undang Nomor 41 Tahun, 1999.

Tentang Kehutanan, Departemen kehutanan.

Usman, 2017. Strategi Pengelolaan Kawasan Konservasi Taman Nasional Bantimurung Bulusaraung di Propinsi Sulawesi Selatan.

Yusran, Suprtaman, Alif, 2010. Pendekatan Kolaborasi Dalam Pengelolaan Taman Nasional Bantimurung Bulusaraung: Strategi Menyatukan Kepentingan Ekoogi dan sosial Ekonomi Masyarakat. Opinion Brief, RECOFTC. Makassar.

Zakaria, Yando. 1994. Hutan dan Kesejahteraan Masyarakat. Jakarta: Wahana Lingkungan Hidup Indonesia (WALHI). 